\title{
Chapter 9 \\ Dry and Humid Periods Reconstructed \\ from Tree Rings in the Former Territory \\ of Sogdiana (Central Asia) and Their \\ Socio-economic Consequences \\ over the Last Millennium
}

\section{Magdalena Opała-Owczarek and Piotr Owczarek}

\begin{abstract}
One of the richest societies along the Silk Road developed in Sogdiana, located in present-day Tajikistan, Uzbekistan, and Kyrgyzstan. This urban civilisation reached its greatest prosperity during the golden age of the Silk Road (sixth to ninth century $\mathrm{CE}$ ). Rapid political and economic changes, accelerated by climatic variations, were observed during last millennium in this region. The newly developed tree-ring-based reconstruction of precipitation for the past millennium revealed a series of dry and wet stages. During the Medieval Climate Anomaly (MCA), two dry periods occurred (900-1000 and 1200-1250), interrupted by a phase of wetter conditions. Distinct dry periods occurred around 1510-1650, 1750-1850, and 1920-1970, respectively. The juniper tree-ring record of moisture changes revealed that major dry and pluvial episodes were consistent with those indicated by hydroclimatic proxy data from adjacent areas. These climate fluctuations have had longand short term consequences for human history in the territory of former Sogdiana.
\end{abstract}

Keywords Arid Central Asia $\cdot$ Silk road $\cdot$ Precipitation reconstruction Dendroclimatology $\cdot$ Social growth and decline

\subsection{Introduction}

Recently, there has been growing interest in the relationship between climate change and its socio-economic consequences throughout human history. Abrupt climate

\footnotetext{
M. Opała-Owczarek ( $ه)$

Department of Climatology, Faculty of Earth Sciences, University of Silesia in Katowice, Będzińska 60, 41-200 Sosnowiec, Poland

e-mail: magdalena.opala@us.edu.pl

P. Owczarek

Department of Physical Geography, Institute of Geography and Regional Development, University of Wroclaw, Pl. Uniwersytecki 1, 50-137 Wrocław, Poland

(C) The Author(s) 2019

L. E. Yang et al. (eds.), Socio-Environmental Dynamics along the Historical Silk Road, https://doi.org/10.1007/978-3-030-00728-7_9
} 
changes not only affect the dynamics of natural systems like glacial and geomorphological processes (Solomina et al. 2016) or the distribution of vegetation zones (Klemm et al. 2016), but may also have long-lasting consequences for societies by causing a rapid transformation of the prevailing hydrological regime (Boroffka et al. 2006; Sorrel et al. 2007). Possible impacts of climate on human life, migration, agricultural production, and the growth and decline of societies have been extensively studied in recent years (Hodell et al. 1995; deMenocal 2001; Weiss and Bradley 2001; Sidle et al. 2004; Buckley et al. 2010; Büntgen et al. 2011; Giosan et al. 2013; Latorre et al. 2016).

The consequences of climate fluctuations are particularly evident in arid and semiarid areas, where ecosystem responses are very rapid. In the long history of the Silk Road, rich ancient societies developed in arid Central Asia under the influence of favourable conditions in the natural environment, where access to water and fertile soil were the most important factors (Owczarek et al. 2018). One of the richest societies along the Silk Road developed in Sogdiana, located in present-day Tajikistan, Uzbekistan, and Kyrgyzstan. This urban civilisation reached its greatest prosperity during the golden age of the Silk Road (sixth to ninth century CE) (Schafer 1963; Litvinsky et al. 1996; de La Vaissière 2002; Marshak 2003; Owczarek et al. 2018). Archaeological excavations indicate that this territory, crossed by several main branches of the Silk Road, was a melting pot where Sogdian merchants met others from a wide range of areas, from China to Byzantium (Marshak 2003). Sogdiana, one of the most advanced areas and the leader of all Transoxania, collapsed in eighth to ninth century (Grenet and de la Vaissière 2002; Marshak 2003). However, Sogdiana's civilizational, economic and social achievements have been visible for many centuries after its decline.

Despite its great significance, this territory, located between the Pamir Mountains and the large mid-latitude desert systems, is relatively little known in terms of climate and socio-economic changes (Opała-Owczarek et al. 2018; Owczarek et al. 2018), in contrast to research showing links between climate and the rise and fall of empires such as the Mongolian (Pederson et al. 2014; Putnam et al. 2016) and Chinese (Fan 2015; Wei et al. 2015; Yin et al. 2016; Li et al. 2017). Recently, Yadava et al. (2016) reconstructed drought periods and historic social upheavals and invasions of India.

The purpose of this paper is to analyse dry and wet periods over the last millennium in the former territory of ancient Sogdiana on the basis of tree-ring data, with a particular focus on the relationship between changes in precipitation and economic growth and decline.

\subsection{Description of the Study Area}

\subsubsection{Regional Settings}

Ancient Sogdiana was located in the upper part of the Aral Sea basin between two large Central Asian rivers, the Amu Darya (Oxus) in the south and the Syr Darya 


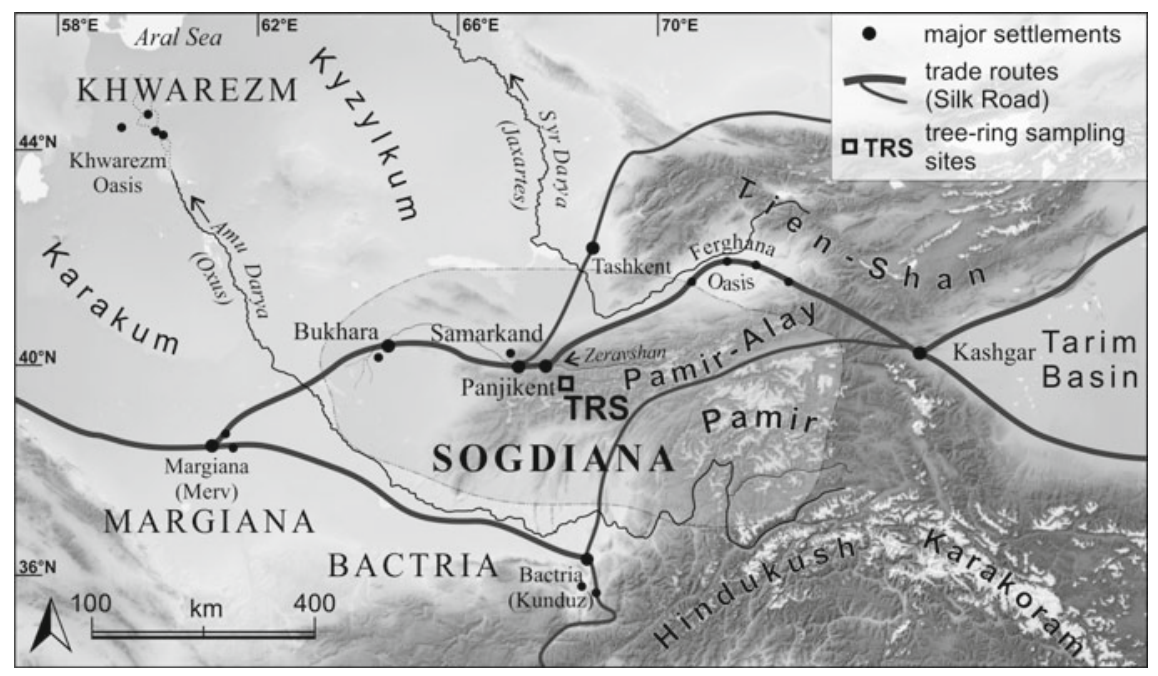

Fig. 9.1 Location of the ancient Sogdiana on the background of political (ca. sixth century AD) and key physiographic units in Central Asia (modified after Abazov 2008)

(Jaxartes) in the north. It stretched from the Pamir Mountains in the east to the Kyzylkum and Karakum deserts in the west (Abazov 2008) (Fig. 9.1). The axis of this territory is marked by the longitudinal Zeravshan River Valley, along which the most important towns of Sogdiana, namely Panjikent, Samarkand, and Bukhara, were situated (Owczarek et al. 2018) (Fig. 9.1). Today this area forms parts of Tajikistan, eastern Uzbekistan, and south-western Kyrgyzstan. The area is characterised by extremely diverse relief. The eastern part includes the partly glaciated Pamir Mountains, where the average height of the main ridges reaches ca $6000 \mathrm{~m}$ a.s.l. (max. Ismail Somoni Peak, 7495 m a.s.l.). The Pamir-Alay Mountains, which form the transition zone between the Pamir and Tien-Shan Mountains, cover the central and north-eastern part of the former territory of Sogdiana. They consist of three longitudinal mountain ridges: Gissar, Zeravshan, and Turkestan, which reach a maximum height of $5600 \mathrm{~m}$ a.s.l. (Rahmonov et al. 2017a, b). These mountainous regions are characterised by a high level of seismicity, connected with their location in the vicinity of the Pamir Frontal Thrust system (Schurr et al. 2014; Owczarek et al. 2017). The western and south-western parts of the former Sogdiana territory include lowlands within the Central Asian mid-latitude desert system (Kyzylkum, Karakum) and tectonically conditioned mid-mountain basins (Afghan-Tajik Depression) (Fig. 9.1).

The tree-ring sampling sites are located in the central part of the Zeravshan Ridge in the Pamir-Alay Mountains (Fig. 9.1). This area is drained by the Urech-Kshtut river system, which constitutes the left tributary of the Zeravshan River. The samples were taken from two sites located in the Urech Valley at elevations between 2200-2900 m a.s.1 (Fig. 9.2a). The upper part of the valley includes a high-mountain glacier basin; surrounded from the south by Chimtarga Peak (5489 m a.s.1) (Fig. 9.2b). Below the basin, the Urech River flows through a deep U-shaped valley with alternating wide 


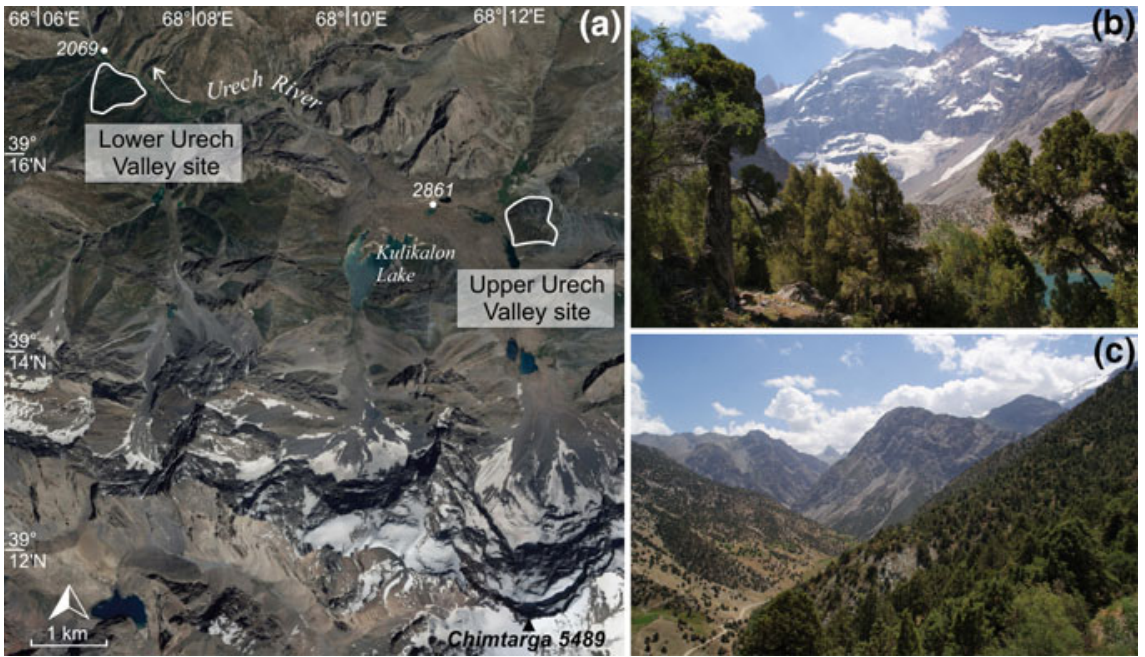

Fig. 9.2 a Location of the tree-ring sampling sites within the highest part of the Zeravshan Range in the Pamir-Alay Mountains (on the basis of 2018 DigitalGlobe, 16 June 2017, Google Earth), b general view of the Upper Urech Valley site, on the background Chimtarga Peak (5489 m a.s.1.); c general view of the Lower Urech Valley site

and narrow zones (Fig. 9.2c). The most important plant community here is composed of Juniperus semiglobosa and Juniperus seravschanica, which form an open forest up to an elevation of $3400 \mathrm{~m}$ a.s.1. (Rahmonov et al. 2017a, b).

\subsubsection{Climate of the Study Area}

The landlocked location of the study area and its great distance from oceanic sources of moisture makes its climate extremely continental, with hot, dry summers and cold winters. Climate conditions are characterised by extreme local contrasts dependent on altitude and landforms. Air temperatures tend to depend strongly on altitude. The mean annual temperature drops from $13.5^{\circ} \mathrm{C}$ at $726 \mathrm{~m}$ a.s.l. in Samarkand to $10.5^{\circ} \mathrm{C}$ at 1680-1700 $\mathrm{m}$ a.s.l. at the mouth of the Urech River, then to $0^{\circ} \mathrm{C}$ at $3200 \mathrm{~m}$ a.s.l. near the upper line of juniper forests, and finally to $-1.8^{\circ} \mathrm{C}$ at the Anzob Pass $(3373 \mathrm{~m}$ a.s.1.) (Fig. 9.3). At the highest peak, Chimtarga, the mean annual temperature is estimated at about $-15^{\circ} \mathrm{C}$ (Rahmonov et al. 2017b).

Mean annual precipitation for the discussed area ranges from 400 to $500 \mathrm{~mm}$ on peaks and slopes at altitudes about 3000-3400 m a.s.1. (434 mm at Anzob Pass) to 250-350 $\mathrm{mm}$ in the Pamir-Alay foreland (353 mm at Samarkand). Most precipitation occurs in spring (about $60 \mathrm{~mm}$ per month in March, April, and May), while the summer months (JJA) receive either minimal quantities or none at all (Fig. 9.3).

Air temperatures in most areas of Tajikistan and Uzbekistan are increasing (0.3-0.5 ${ }^{\circ} \mathrm{C}$ in the period 1940-2000, with the warmest decades in the 1930s, 1980s and 1990s); however, changes in atmospheric precipitation are uneven due to the 

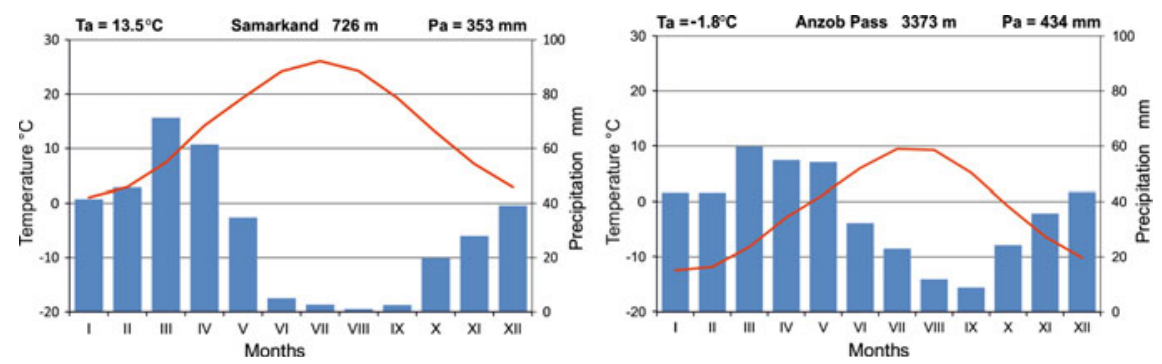

Fig. 9.3 Monthly mean temperature and mean precipitation for Samarkand and Anzob Pass meteorological stations during the period 1936-2003 on the basis of data from CATPD (Williams and Konovalov 2008)

geographic and climatic diversity of the territory (Makhmadaliev et al. 2008; Chub and Ososkova 2009; Kayumov 2010). In Uzbekistan, observed changes in the hydrological cycle include a decrease in precipitation in the west and an increase in the east of the country as well as around irrigated lands along main river valleys due to increased evaporation (Lioubimtseva and Henebry 2009; Chub and Ososkova 2009). The eastern part of the studied area, covering the territory of Tajikistan, experiences more humid conditions. In general, periods of humid weather alternate with periods of dry weather. According to available instrumental climate data the driest decade for all altitudinal zones was from 1941 to 1950. A trend towards increasing amounts of precipitation is especially visible in the second half of the twentieth century. After 1990, the rainiest period was in 1998-99; the following years 2000-01 were the driest, with drought predominating nearly throughout the territory.

\subsection{Materials and Methods}

\subsubsection{Tree Ring Sampling and Development of Chronologies}

In 2014 and 2015, we collected 110 cores using increment borers $(5.15 \mathrm{~mm}$ in diameter). To minimise non-climatic effects on tree growth, only uninjured, healthy trees were sampled. Tree cores from junipers were collected from two sampling plots (Fig. 9.2a). The Upper Urech Valley site (UUV) is situated in a high mountain basin, partly filled by one of the Kulikalon Lakes, at an altitude of 2800-2900 m a.s.l. (Fig. 9.2b). The second site, the Lower Urech Valley site (LUV), is located at an elevation of 2200-2300 m a.s.l. on a valley slope (Fig. 9.2c).

According to standard dendrochronological techniques (Speer 2010), the sampled tree-ring cores were dried naturally and sanded to a high polish using progressively finer grades of sandpaper until the cellular structures of the rings were visible under a binocular. Ring widths were measured to the nearest $0.001 \mathrm{~mm}$ using the WinDENDRO system (WinDENDRO 2006). Next, we used the COFECHA program (Holmes 1983) to check our dating by comparing ring-width measurements between all series from the two sites. Before calibrating the tree-ring data with climate data, the bio- 
logical age trend inherent in the raw data series had to be removed. We used the ARSTAN program (Cook 1985) to detrend individual series with a negative exponential curve to preserve climate-related variations at both high and low frequencies. The chronology was calculated as the residuals between the raw measurements and fitted trend curves, resulting in a dimensionless index series. The detrended single series were then combined into a standard chronology, using a biweight robust mean to minimise the influence of biases in tree-ring indices (Cook and Kairiukstis 1990). The reliability of the tree-ring records was evaluated using the so-called expressed population signal (EPS) (Wigley et al. 1984). To assess replication through time at every site, we used the commonly acceptable cut-off value of 0.85 (85\% of common chronology signal retained) and an adequate sample size (series $\geq 3$ ).

\subsubsection{Climatological Data and Dendroclimatic Methods}

The longest series of meteorological data for the studied region is available from the Samarkand meteorological station in Uzbekistan (station code $38696,67.00^{\circ} \mathrm{E}$, $39.70^{\circ} \mathrm{N}, 726 \mathrm{~m}$ a.s.1.). Meteorological station data were obtained from Central Asia Temperature and Precipitation Data (CATPD), 1879-2003 (Williams and Konovalov 2008). Monthly temperature means and precipitation sums for the period 1936-2015 were used in our calculations. These were also compared to monthly $0.5^{\circ} \times 0.5^{\circ}$ gridded climate variables obtained from the Climatic Research Unit (CRU TS 3.21, Mitchell and Jones 2005). For calculation, we used data averaged for the mountainous region $39-40^{\circ} \mathrm{N}$ and $68-69^{\circ} \mathrm{E}$, the mountain foreland region $37-38^{\circ} \mathrm{N}$ and $67-68^{\circ} \mathrm{E}$, and the average of the grids $38-41^{\circ} \mathrm{N}$ and $67-70^{\circ} \mathrm{E}$, which equally represent the climates of the mountainous part and low elevations of the study area. A comparison between the precipitation levels noted in various meteorological records available for the region is shown in Fig. 9.4.

The relationship between juniper ring width variations and climate was determined by calculating a response function and conducting a correlation analysis between the site-level chronologies, mean monthly temperature, and total monthly precipitation over the so-called 'dendroclimatological year'. As the growth of a tree can be affected by the climatic conditions of the current as well as those of the previous growing season, climate response analysis was performed from monthly data from the previous July to the current September. For calculations we used the DendroClim2002 program (Biondi and Waikul 2004), which provides estimates of bootstrapped confidence intervals for evaluating the significance of correlation coefficients. Following the successful verification and calibration procedure, the climate reconstruction was performed using the transfer function described by Cook and Kairiukstis (1990). 


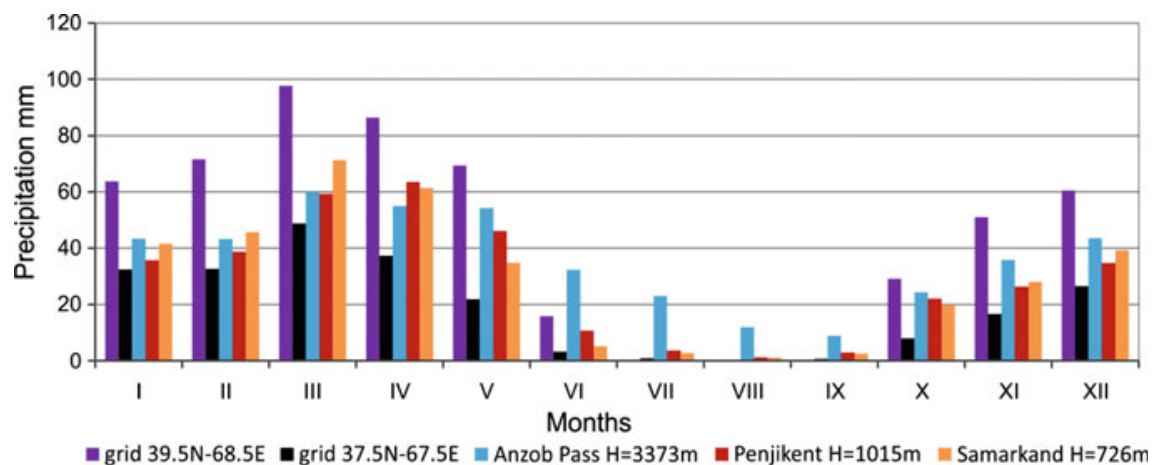

Fig. 9.4 A comparison between the precipitation levels noted in various meteorological records available for the central part of former Sogdiana territory (present-day north-western Tajikistan, eastern Uzbekistan) on the basis of CATPD dataset (Williams and Konovalov 2008) and Climate Research Unit (CRU) TS 2.1 gridded dataset (Mitchell and Jones 2005)

\subsection{Results and Discussion}

\subsubsection{Characteristics of Tree-Ring Chronology and Its Response to Climate}

The constructed local site chronologies showed a significant inter-site correlation of 0.49 , which indicates a common climatic signal. The chronology from the lower site (LUV) covers the last 220 years (1795-2014, with EPS >0.85 from AD 1877); the time span of the chronology from the upper site (UUV) was much longer, covering the last 1215 years (801-2015, with EPS $>0.85$ from AD 1092). Difference between the length of these two chronologies is connected with timber harvesting in the vicinity of settlements, that lasts already for many centuries.

Climate response analysis showed that local chronologies are positively correlated with monthly precipitation, while the influence of temperature is minor or insignificant. In general, both chronologies are positively correlated with the monthly precipitation from the previous July to the current September recorded at the meteorological station in Samarkand. The highest significant correlations were found between tree-ring widths from the lower location and spring precipitation (March-May, $\mathrm{r}=$ 0.60; April-May, $r=0.58$ ). As shown in Fig. 9.5, the correlation coefficient values for the upper location, though slightly lower, indicate a similar growth response to climatic variability. Significant correlations were found with mean monthly precipitation in spring months (April-May) and precipitation in the dendroclimatological year (pJune-September). The correlations between the gridded precipitation data were consistent to some extent with the correlations observed with weather station data (Fig. 9.5). 

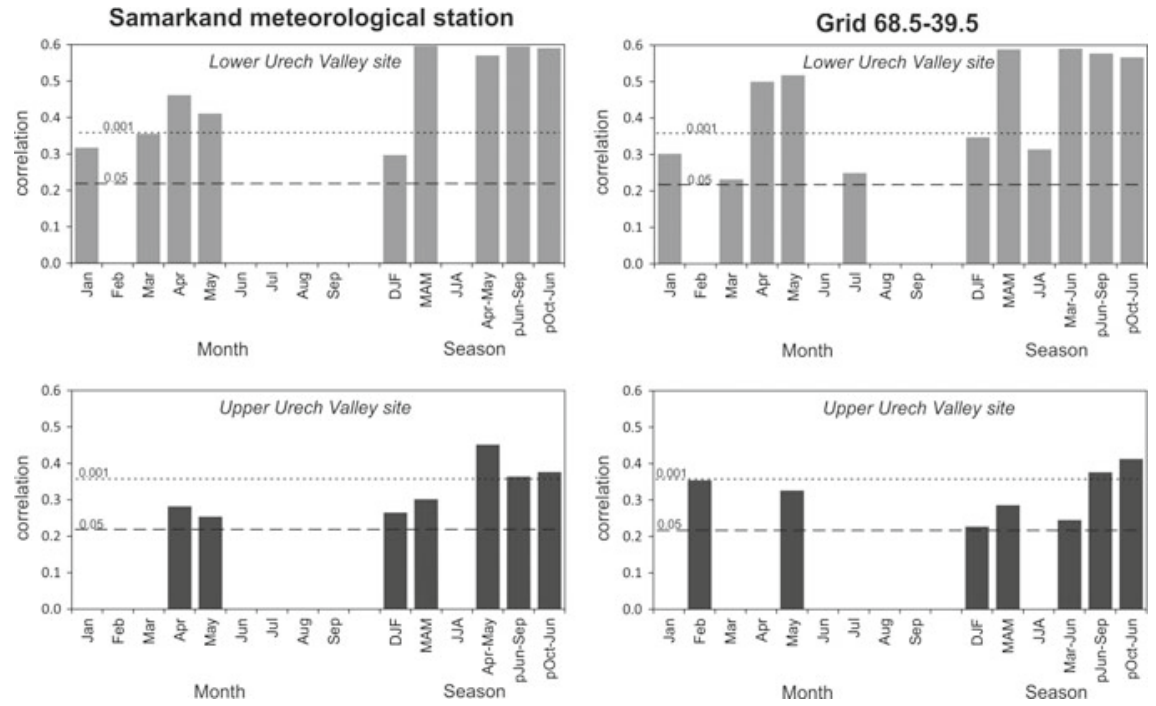

Fig. 9.5 Correlation between juniper tree-ring width chronologies from lower and upper Urech Valley study sites and precipitation data from Samarkand $(726 \mathrm{~m})$ and gridded dataset $(68.5-39.5)$

In earlier studies it was also noted that pluvial conditions during the winter months are very important for the growth of trees from southern slopes near timberline locations in the Pamir-Alay (Opała et al. 2017; Opała-Owczarek and Niedźwiedź 2018). Moreover, Seim et al. (2016) stated that junipers growing on the southern slopes in Uzbek part of the Pamir-Alay and Tien-Shan are mainly dependent on spring and annual precipitation. Differences in seasonal response are connected with local conditions (altitude, topography, location within the mountain massif). Moisture supply in the early growing season (from liquid precipitation or snowmelt) is the most important climate variable affecting the growth of junipers. As summer precipitation in the studied region is scarce, drought stress is expected to be one of the main growth limiting factors for these trees.

The significant climate-growth correlations enabled us to reconstruct April-May precipitation anomalies from the tree-ring-width chronology of junipers. The highelevation chronology was used to calculate the reconstruction, as it allows to cover the longer time span. The moving correlation analysis indicated that the climate-growth relationship is stable only in the second part of the instrumental data period (Fig. 9.6a). Such result is usually associated with the low quality of the instrumental data in the early period of observations, but it may be not a single factor. Other possible causes are e.g. dust storms in arid Central Asia, which were especially frequent during the 1950-60s, when vast areas of natural desert pastures were dramatically transformed by agriculture and human pressure. This led to increase in the frequency of dust storms outbreaks (Indoitu et al. 2012). Therefore, we used shortened period 1966-2014 for calibration with proxy data (Fig. 9.6b). 

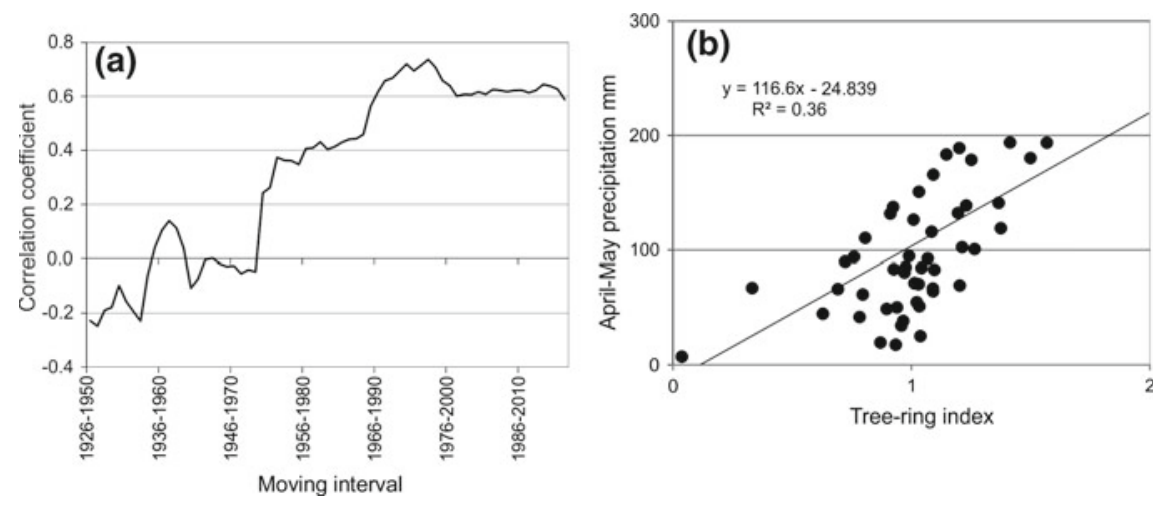

Fig. 9.6 a Moving correlation function between April-May precipitation and the tree-ring width index from the upper site chronology considering an interval lengths of 25 years; $\mathbf{b}$ the relation between these variables over the period 1966-2014

The regression model accounts for $36 \%$ of the variance in the instrumental spring precipitation (April-May totals) over the calibration period from 1966-2014. The results of ca $30-40 \%$ of explained variance in the dendroclimatic reconstruction is widely acceptable (e.g. Chen et al. 2015; Gou et al. 2015; Shah et al. 2018). We are aware that the dendroclimatic method of climate reconstruction is associated with a certain degree of uncertainty. However, standard methodology have been used to assess whether the model has the ability to reconstruct the climate. The cross calibration-verification tests for two split periods revealed that the model passes the standard tests of reconstruction reliability (a positive reduction of error (RE) and coefficient of efficiency (CE)). Because our calibration-verification sub-periods are relatively short (1966-1990, 1990-2014), additional verification of spring precipitation reconstruction model was made using a grid dataset (Table 9.1). Finally, a linear regression model was developed to reconstruct April-May precipitation variations back to $800 \mathrm{CE}$. The reconstruction of spring precipitation variability over the last 1200 years presented in Fig. 9.7 revealed variations on an inter-annual to decadal and centennial scale.

\subsubsection{Moisture Changes in the Last Millennium}

The reconstructed climate history of the former territory of Sogdiana for the past millennium revealed a series of dry and wet stages. Referring to the time frame of the Medieval Climate Anomaly (900-1300 CE) and the Little Ice Age (1570-1900 CE) described by Lamb (1965) and Matthews and Briffa (2005) some regional differences can be observed. In the studied western Pamir-Alay region during the Medieval Climate Anomaly (MCA) two dry periods occurred, with a shift to wetter conditions 
Table 9.1 Calibration and verification statistics for split (1966-1990, 1990-2014) and entire period (1990-2014) for the spring precipitation reconstruction model based on tree rings

\begin{tabular}{l|l|l|l|l|l|l}
\hline $\begin{array}{l}\text { Type of } \\
\text { data }\end{array}$ & \multicolumn{3}{|l|}{ Samarkand station data } & $\begin{array}{l}\text { Samarkand } \\
\text { station data }\end{array}$ & Grid data $^{\mathrm{a}}$ \\
\hline Time period & $\begin{array}{l}\text { Calibration } \\
(1990-2014)\end{array}$ & $\begin{array}{l}\text { Verification } \\
(1966-1990)\end{array}$ & $\begin{array}{l}\text { Calibration } \\
(1966-1990)\end{array}$ & $\begin{array}{l}\text { Verification } \\
(1990-2014)\end{array}$ & $\begin{array}{l}\text { Calibration } \\
(1966-2014)\end{array}$ & $\begin{array}{l}\text { Verification } \\
(1966-2014)\end{array}$ \\
\hline $\mathrm{r}$ & 0.65 & 0.62 & 0.62 & 0.64 & 0.60 & 0.56 \\
\hline $\mathrm{R}^{2}$ & 0.41 & 0.38 & 0.38 & 0.41 & 0.36 & 0.32 \\
\hline $\mathrm{RE}$ & & 0.41 & & 0.42 & & 0.21 \\
\hline $\mathrm{CE}$ & & 0.38 & & 0.40 & & 0.18 \\
\hline $\mathrm{ST}+/-$ & & $19 / 6$ & & $21 / 4$ & & $34 / 14$ \\
\hline
\end{tabular}

Explanations: $\mathrm{r}$-correlation coefficient; R2—explained variance; RE reduction of error; CE coefficient of efficiency; ST sign test

${ }^{\mathrm{a}}$ For independent verification data for grid $\left(38-41^{\circ} \mathrm{N}\right.$ and $\left.67-70^{\circ} \mathrm{E}\right)$ was used

between them. The Little Ice Age (LIA) in this area was characterised by wetter conditions interrupted by a dry period with conditions closer to the average (Fig. 9.7).

According to new Pamir-Alay tree-ring data, dry periods prevailed in the following time spans: $900-1000,1200-1250,1510-1650,1750-1850$, and 1920-1970 (Fig. 9.7b). The first long period of arid climate conditions present in the tree-ringbased precipitation reconstruction started as early as 900 and lasted to ca $1000 \mathrm{CE}$. This drought is consistent with data from the Guliya ice cap (Thompson et al. 1995; Yao et al. 1996) and Badain Jaran Desert (Ma and Edmunds 2006), and is also in line with the modelled changes in rainfall anomalies of the ECHAM5 simulation of the arid Central Asia domain (Fallah et al. 2016). At the turn of the tenth and eleventh centuries, a shift to wetter conditions occurred. This period of two hundred years is characterised by a high level of variability with a clear predominance of above-average precipitation. Increased rainfall in Central Asia in this period is evidenced by low-resolution records, such as speleothem carbon isotope data, ostracod assemblages from lake sediments, and pollen concentration data (Chen et al. 2010).

At the beginning of the thirteenth century, a rapid transition to dry conditions is observed. This period lasted only fifty years, but probably constituted the most severe drought in the entire analysed period. Low precipitation before ca 1250 was confirmed by many other natural proxies from arid Central Asia, e.g. Uluu Too Cave (Wolff et al. 2017). After a period of considerable higher precipitation from 1300 to 1400 , a homogeneous period of nearly 200 years, with values close to the longterm average, prevailed during the fifteenth century, becoming progressively drier during the sixteenth century. The occurrence of low levels of precipitation and very dry conditions during this time is confirmed by historical reports from Afghanistan (Beveridge 1921, after Yadava et al. 2016). A rapid transition between dry and wet climate conditions took place around 1650 . The two most significant pluvial periods in the Pamir-Alay tree-ring reconstruction, around the eleventh and twelfth and from the mid-seventeenth to mid-eighteenth centuries, are in accord with data on PamirAlay glacier fluctuations (Solomina et al. 2016). The evidence for a glacier advance 


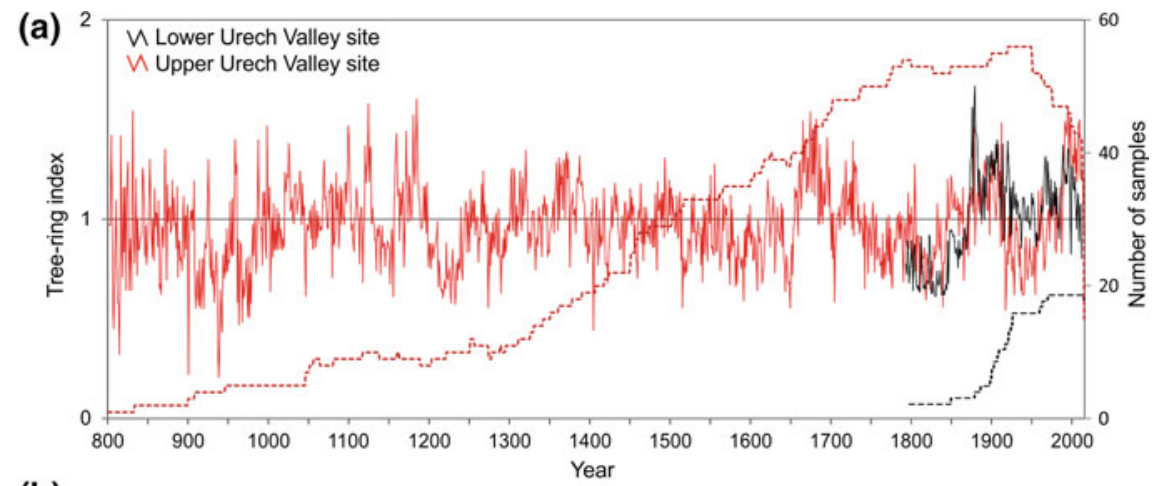

(b)

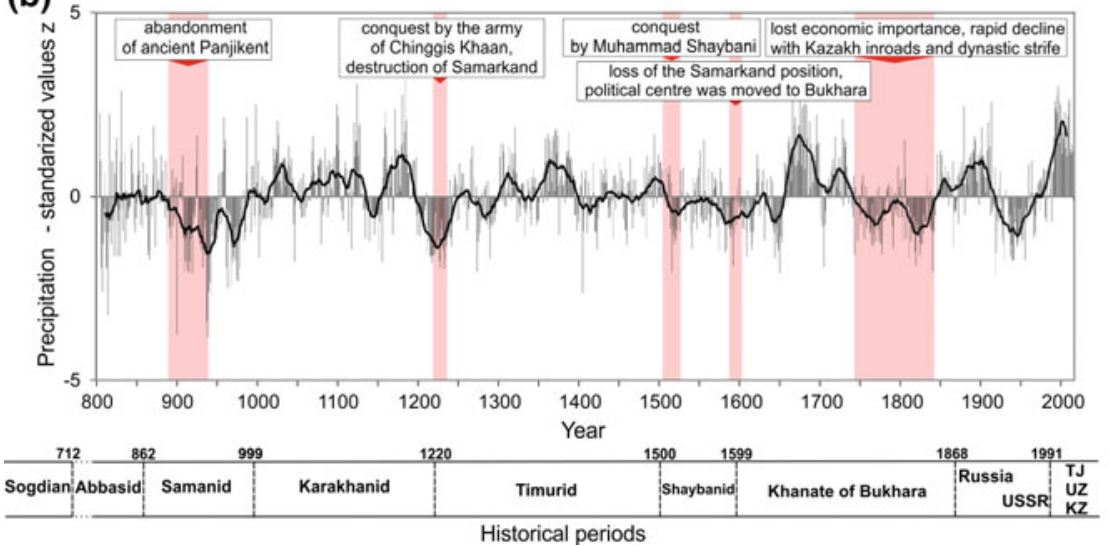

Fig. 9.7 a Tree-ring width chronology of Juniperus seravshanica from the lower Urech Valley (1795-2014) and Juniperus semiglobosa from the upper Urech Valley (801-2015). The solid and dashed lines represent the tree-ring index and sample depth, respectively. b Tree-ring-based reconstruction of precipitation variability during the past 1200 years with important historical periods for the former territory of Sogdiana. The vertical red bands denote dry periods, which correlate with rapid political and economic changes

shortly after $985 \pm 115 \mathrm{CE}$ was found via radiocarbon dating of shallow soil horizon below a fresh till at the Abramova Glacier (Zech et al. 2000). The youngest advance took place at the end of the seventeenth century (ca $1690 \mathrm{CE}$ ) as dated by a ${ }^{14} \mathrm{C}$ age determined from a trunk of Juniperus turkestanica broken by an advance of the Raigorodskogo Glacier (Narama 2002). In the light of glaciological evidence, these two advances were of similar magnitude, although the former was slightly larger.

The Pamir-Alay tree-ring reconstruction shows that LIA precipitation maximum (1650-1740) was followed by a long dry period, 1750-1840 (Fig. 9.7b). The first dry sub-period, 1756-1768, known as the Strange Parallel Drought, is well documented in different parts of Asia. Of the four well-documented historical droughts indicated in the Monsoon Asia Drought Atlas (MADA, Cook et al. 2010), it was the only mega-drought to occur in the studied area. At the end of the LIA, a pronounced wet 
period took place around 1850-1910, followed by advances of the Raigorodskogo Glacier dated to 1908-1934 (Narama 2002).

The twentieth century was characterised by two opposing precipitation regimes. A pronounced drought was observed between ca 1920 and 1970. A significant change in precipitation variability is evident during the second half of the twentieth century. The recent wetting trend in Central Asia was captured by many moisture-sensitive tree-ring series, e.g. from north-western India (Yadav et al. 2017), northern Pakistan (Treydte et al. 2006) and Kyrgyzstan (Chen et al. 2015; Zhang et al. 2015), as opposed to the case of Mongolia or of Nepal, where contemporary drought is evident (Pederson et al. 2014; Panthi et al. 2017).

\subsubsection{Socio-economic Changes During the Past Millennium}

The oasis of Samarkand in the Middle Zeravshan Valley was the most important political and economic centre at the turn of the first and second millennium of the common era. Samarkand was the capital of ancient Sogdiana, which collapsed in the eighth century; nevertheless, it maintained its importance in the following centuries. During this time, the area was in the possession of various tribes and dynasties (Fig. 9.7). Political changes, both negative and positive, in the former territory of the kingdom of Sogdiana, as reflected in the history of Samarkand, were often associated with climate changes, i.e. the occurrence of alternate dry and humid periods (Owczarek et al. 2018).

Following the Arab conquest at the beginning of the eighth century, most of the former Sogdiana area fell into the orbit of Islamic influence (Grenet and de la Vaissière 2002; Marshak 2003; Ghafurov 2011). The period ca 800-900 was characterised by relatively warmer and wetter climate conditions. This is confirmed not only by tree-ring data but also by other proxy data from the Aral Sea basin and the surrounding areas (Sorrel et al. 2006, 2007; Boomer et al. 2009). During this time Samarkand and its surroundings became part of the Samanid Empire. This period of prosperity was experienced not only in this area but along the entire Silk Road as well. Public buildings and mosques were enlarged and the water supply ensured by means of ancient aqueducts, conduits, and irrigation canals (Ivanitskij and Inevatkina 1999; Malatesta et al. 2012). Samarkand's oases, with their famous peach gardens, experienced a golden age at the end of the Tang Dynasty (Schafer 1963). Despite the tenth-century drought, the economy of Samarkand remained unaffected. This cannot be said of the nearby town of Panjikent, one of the most important cities in ancient Sogdiana and along the Silk Road (Fig. 9.8) (Belenitskij et al. 1973). Although the Arab conquest in 722 did not cause its definitive collapse, Panjikent gradually lost its significance in comparison to Samarkand and Bukhara (Marshak 2003). A period of drought in the tenth century was one of the influences leading to the abandonment of ancient Panjikent and the town's displacement to the lower terrace of the Zeravshan River, where water was more accessible (Fig. 9.8) (Owczarek et al. 2018). The arid conditions during this time have also been clearly documented by 


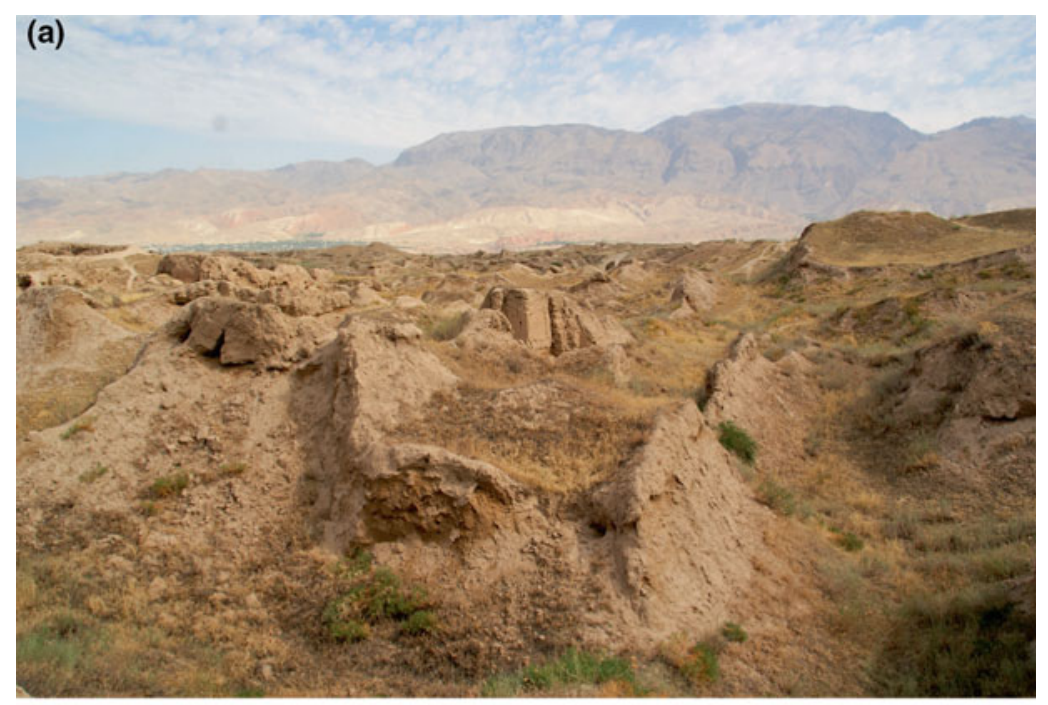

(b)

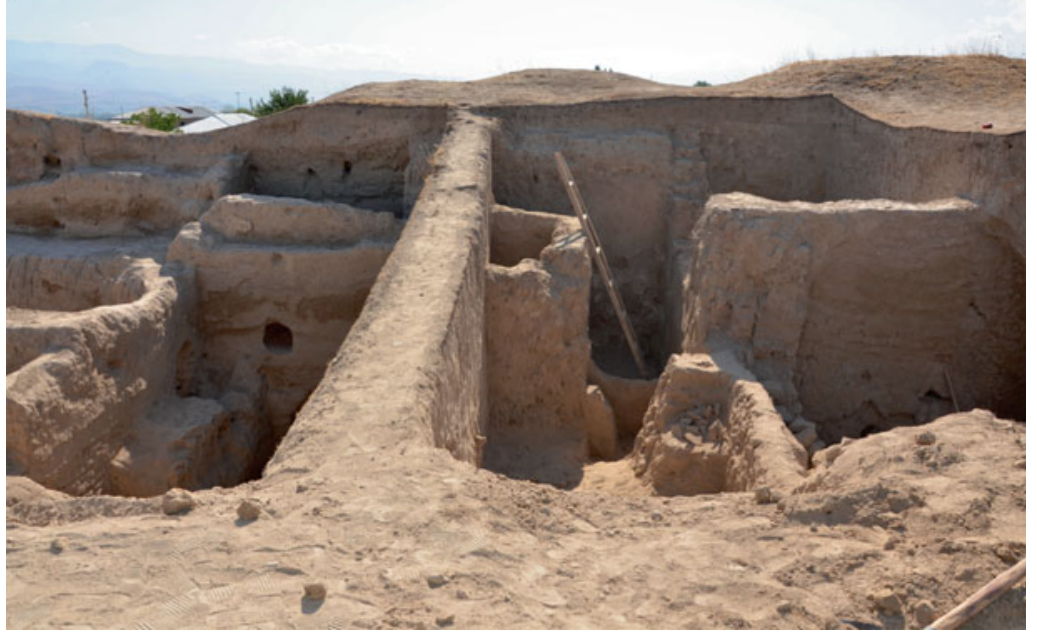

Fig. 9.8 a General view of the ruins of ancient Panjikent, partly destroyed during Arab conquest in AD 722 and completely abandoned in the 9th/10th century, $\mathbf{b}$ archaeological excavation within the area of ancient Panjikent (photographs were taken in July 2015 by the authors)

means of pollen analysis of sediments from the northern shore of the Aral Sea (Sorrel et al. 2007) and other palaeoclimatic records from arid Central Asia (Yang et al. 2009). In the eleventh and twelfth centuries, in stable moisture climate conditions, the former Sogdiana area became part of the Karakhanid Khanate. This period was marked by continued development for Samarkand as a new administrative centre. Several buildings were erected, including a new palace in the citadel, a madrasa, and 
caravansaries (Davidovich 1998). The Bibi-Khanym Mosque was enlarged and, to a great extent, rebuilt (Grenet and Rapin 1993; Paul 1993).

The tree-ring data from the first half of the thirteenth century documented strong arid conditions (Fig. 9.7). This dry period was also marked by the increasing salinity of the Aral Sea (Sorrel et al. 2006), a high level of carbonate content in lake sediments (Chen et al. 2006), and falls in the levels of lakes in arid Central Asia (Boroffka et al. 2006; Narama et al. 2010), and diminishing ice accumulation in Central Asian glaciers (Yang et al. 2009). This period was marked by drastic political and economic changes in the area of former Sogdiana. In 1220, Samarkand was seized by the army of Chinggis Khaan and destroyed (Grenet and Rapin 1993). The huge losses sustained by the working population and the decreasing availability of water in connection with the dry climate conditions were the main factors contributing to the decline of Samarkand, as maintenance of the water supply required more skills and labour than were available (de Hartog 2006). The increasing humidity in the fourteenth century coincided with the rebuilding of Samarkand and re-establishment of its significance. In 1371, Timur established the city as his capital and renewed the irrigation system in the Zeravshan River valley, which was used extensively for agriculture (Manz 1989). Traces of a high water level and flooding in this period, indicating a moister climate, were found in sediment from canals carrying water from the Zeravshan River to the oases of Samarkand (Malatesta et al. 2012). The next arid interval, recorded ca 1500-1600, was marked again by violent political changes in the former Sogdiana (Fig. 9.7).

In 1500, Timurid Samarkand was conquered by Muhammad Shaybani (Grenet 2002; Mukminova and Mukhtarov 2003). The gradual decline in the importance of the Silk Road in the sixteenth century coincided with the prevailing arid conditions and the loss of Samarkand position. The political centre of the former territory of Sogdiana moved to Bukhara, which became the capital of the Khanate (Mukminova and Mukhtarov 2003). Sixteenth-century aridification was confirmed by an increase in salinity and changes of lake levels of the Aral Sea (Sorrel et al. 2006; Boomer et al. 2009; Boroffka et al. 2006). The rapid increase in humidity in the second part of the seventeenth century was marked by flood sediments in the irrigation canals in the Samarkand oasis (Malatesta et al. 2012). During the period 1750-1850, a return to arid conditions was documented. The former territory of Sogdiana lost its economic importance along with the collapse of trade on the Silk Road. A rapid decline occurred in the second part of the eighteenth century, with the inroads made by the Kazakhs and dynastic strife (Fig. 9.7). The Samarkand oasis was depopulated and the madrasas were converted by nomads into winter stables (Grenet 2002). The wet period in the second part of the nineteenth century coincided with Russian expansion. In 1868, Samarkand was conquered by the Russians and the remainder of the area of the former Sogdiana became an informal Russian protectorate (Fourniau and Poujolvc 2005). The last aridification interval occurred in the middle of the twentieth century. This was a period of rapid socio-economic changes in the Soviet republics of Central Asia. Arid conditions exerted a negative influence on increased human activity and unsustainable farming. 


\subsection{Conclusions}

Our dendroclimatic reconstruction of changes in spring precipitation, which covers important climatic periods of the last millennium, including the drier Medieval Climate Anomaly, the wetter Little Ice Age, and modern times, revealed a series of dry and wet stages. Despite our tree-ring data were collected from relatively limited area, the newly developed proxy record of moisture changes revealed that major dry and wet episodes over the past millennium were consistent with those indicated by other hydroclimatic proxy data (such as speleothems, pollen data, glacier retreats or ice accumulation, lake sediments or changes in lake levels) from adjacent areas.

In general, during dry periods, negative socio-economic changes were observed. Our palaeoclimatic data show drought during the tenth century, influencing the abandonment of ancient Panjikent. The next dramatic decrease in precipitation took place in the first half of the thirteenth century. This period was marked by drastic political and economic changes in the former territory of Sogdiana, as Samarkand was destroyed by the army of Chinggis Khaan and additionally suffered from decreasing water availability, leading to a decline in its importance. Severe drought conditions also occurred in the sixteenth century, contributing to a deterioration in living conditions which coincided with the decline of the importance of the Silk Road and, finally, the loss of Samarkand position. On the other hand, wetter climatic conditions led to improvements in living conditions, followed by expansion and development, as was particularly evident in the eleventh, twelfth, fourteenth, and seventeenth centuries. A socio-economic perspective of wet conditions in the historic past reveals the great vulnerability of societies in arid Central Asia to climate change. However, one should keep in mind that climate may trigger problems in a society, but does not necessarily automatically lead to collapse of cultures.

Acknowledgements The authors wish to thank local people from Sughd Province and Rahmonov family for their hospitality. We are grateful to Oimahmad Rahmonov for logistic support and assistance in the field. We acknowledge Tadeusz Niedźwiedź for providing Samarkand meteorological data. This study was performed within the scope of the research project no. 2013/09/B/ST10/00634 "Comparison of thermal variability during the last millennium in the mountains of Central Asia and Central Europe" funded by the Polish National Science Centre (NCN). P. Owczarek was financed by statutory founds of the University of Wroclaw.

\section{References}

Abazov, R. (2008). Palgrave concise historical atlas of Central Asia. New York: Palgrave Macmillan US.

Belenitskij, A. M., Bentovich, I. B., \& Bol'shakov, O. G. (1973). Srednevevovyı̆ gorod Sredně Azii (The medieval town in Central Asia). Leningrad: Nauka Press.

Beveridge, A. S. (1921). Babur-Nama (Memoirs of Babur) (Translated from the Original Turki Text of Zahiru'd-din Muhammad Babur Padshah Ghazi). Delhi: D. K. Fine Art Press Pvt. Ltd. 
Biondi, F., \& Waikul, K. (2004). DENDROCLIM2002: A C++ program for statistical calibration of climate signals in tree-ring chronologies. Computers \& Geosciences, 30, 303-311.

Boomer, I., Wünnemann, B., Mackay, A. W., Austin, P., Sorrel, P., Reinhardt, C., et al. (2009). Advances in understanding the late Holocene history of the Aral Sea region. Quaternary International, 194, 79-90. https://doi.org/10.1016/j.quaint.2008.03.007.

Boroffka, N., Oberhänsli, H., Sorrel, P., Demory, F., Reinhardt, C., Wünnemann, B., et al. (2006). Archaeology and climate: Settlement and lake-level changes at the Aral Sea. Geoarchaeology, 21, 721-734. https://doi.org/10.1002/gea.20135.

Buckley, B. M., Anchukaitis, K. J., Penny, D., Fletcher, R., Cook, E. R., Sano, M., et al. (2010). Climate as a contributing factor in the demise of Angkor, Cambodia. Proceedings of the National Academy of Sciences, 107(15), 6748-6752. https://doi.org/10.1073/pnas.0910827107.

Büntgen, U., Tegel, W., Nicolussi, K., et al. (2011). 2500 years of European climate variability and human susceptibility. Science, 331(6017), 578-582.

Chen, F., He, Q., Bakytbek, E., Yu, S., \& Zhang, R. (2015). Climatic signals in tree rings of Juniperus turkestanica in the Gulcha River Basin (Kyrgyzstan), reveals the recent wetting trend of high Asia. Dendrobiology, 74, 35-42. https://doi.org/10.12657/denbio.074.004.

Chen, F. H., Chen, J. H., Holmes, J., Boomer, I., Austin, P., Gates, J. B., et al. (2010). Moisture changes over the last millennium in arid central Asia: A review, synthesis and comparison with monsoon region. Quaternary Science Reviews, 29, 1055-1068.

Chen, F., Huang, X., Zhang, J., Holmes, J. A., \& Chen, J. (2006). Humid little ice age in arid central Asia documented by Bosten lake, Xinjiang, China. Science in China Series D: Earth Sciences, 49(12), 1280-1290.

Chub, V., \& Ososkova, T. (2009). The second national communication of the republic of Uzbekistan under the United Nations framework convention on climate change. Uzbekistan: Tashkent.

Cook, E. R. (1985). A time series approach to tree-ring standardization. Ph.D. Dissertation. Tucson, AZ, USA: University of Arizona.

Cook, E. R., \& Kairiukstis, L. A. (1990). Methods of dendrochronology. Dordrecht, The Netherlands: Kluwer Academic Publishers and International Institute for Applied System Analysis.

Cook, E. R., Anchukaitis, K. J., Buckley, B. M., D’Arrigo, R. D., Jacoby, G. C., \& Wright, W. E. (2010). Asian monsoon failure and megadrought during the last millennium. Science, 328 , 486-489.

Davidovich, E. A. (1998). The Karakhanids. In M. S. Asimov \& C. E. Bosworth (Eds.), History of civilizations of Central Asia volume IV, the age of achievement: A.D. 750 to the end of the fifteenth century. Multiple History Series, Paris: UNESCO Publishing.

de Hartog, L. (2006). Genghis Khan: Conqueror of the world. New York: Pauris Parke-Palgrave Mcmillan Press.

de La Vaissière, E. (2002). Histoire des marchands sogdiens. Paris: Institut des Hautes Etudes Chinoises, Collège de France.

deMenocal, P. B. (2001). Cultural responses to climate change during the Late Holocene. Science, 292(5517), 667-673.

Fallah, F., Sodoudi, S., \& Cubasch, U. (2016). Westerly jet stream and past millennium climate change in Arid Central Asia simulated by COSMO-CLM model. Theoretical and Applied Climatology, 124, 1079-1088. https://doi.org/10.1007/s00704-015-1479-x.

Fan, K. W. (2015). Climate change and Chinese history: A review of trends, topics, and methods. WIREs Climate Change, 6, 225-238. https://doi.org/10.1002/wcc.331.

Fourniau, V., \& Poujolvc, C. (2005). The states of Central Asia (second half of nineteenth century to early twentieth century). In M. K. Palat \& A. Tabyshalieva (Eds.), History of civilizations of Central Asia volume V, towards the contemporary period: from the mid-nineteenth to the end of the twentieth century. Multiple History Series, Paris: UNESCO Publishing.

Ghafurov, B. (2011). Tajiks: Pre-ancient, ancient and medieval history. Dushanbe, Tajikistan: Ministry of Culture of the Republic of Tajikistan, Irfon.

Giosan, L., Fuller, D. K., Nicoll, K., Flad, R. K., \& Clift, P. D. (2013). Climates, landscapes, and civilizations (p. 198). Geophysical Monograph Series: American Geophysical Union. 
Gou, X., Gao, L., Deng, Y., Chen, F., Yang, M., \& Still, C. (2015). An 850-year tree-ring-based reconstruction of drought history in the western Qilian Mountains of northwestern China. International Journal of Climatology, 35, 3308-3319. https://doi.org/10.1002/joc.4208.

Grenet, F., \& Rapin, C. (1993). De la Samarkand antique à la Samarkand islamique: continuités et ruptures. In R. P. Gayraud (Ed.), Actes du Colloque International Archéologie Islamique du Caire. Paris: Institut Français D'archéologie Orientale.

Grenet, F. (2002). Samarqand: History and archeology. Encyclopedia Iranica online. Originally Published: July 20, 2002 available at http://www.iranicaonline.org/articles/samarqand-i. Accessed on 16 Aug 2017.

Grenet, F., \& de la Vaissière, E. (2002). The last days of Panjikent. Silk Road Art and Archaeology, $8,155-196$.

Hodell, D. A., Curtis, J. H., \& Brenner, M. (1995). Possible role of climate in the collapse of classic Maya civilization. Nature, 375, 391-394.

Holmes, R. L. (1983). Computer assisted quality control in tree-ring dating and measurement. Tree-Ring Bulletin, 43, 69-78.

Indoitu, R., Orlovsky, L., \& Orlovsky, N. (2012). Dust storms in Central Asia: Spatial and temporal variations. Journal of Arid Environments, 85, 62-70.

Ivanitskij, E. D., \& Inevatkina, O. N. (1999). Periodizatsiya i etapy razvitiya vodosnabzheniya Afrasiaba (Periods and stages of the development of the water-supply of Afrasiab). Istoriya Material'noŭ Kul'tury Uzbekistana, 30, 96-103.

Kayumov, A. (2010). Glaciers resources of Tajikistan in condition of the climate change. Dushanbe, Tajikistan: State Agency for Hydrometeorology of Committee for Environmental Protection under the Government of the Republic of Tajikistan.

Klemm, J., Herzschuh, U., \& Pestryakova, L. A. (2016). Vegetation, climate and lake changes over the last 7000 years at the boreal treeline in north-central Siberia. Quaternary Science Reviews, 147, 422-434.

Lamb, H. H. (1965). The early medieval warm epoch and its sequel. Palaeogeography, Palaeoclimatology, Palaeoecology, 1, 13. https://doi.org/10.1016/0031-0182(65)90004-0.

Latorre, C., Wilmshurst, J. M., \& von Gunten, L. (2016). Climate change and cultural evolution. Past Global Change Magazine, 24(2), 53-84.

Li, J., Dodson, J., Yan, H., Zhang, D. D., \& Zong, Y. (2017). Quantifying climatic variability in monsoonal northern China over the last 2200 years and its role in driving Chinese dynastic changes. Quaternary Science Reviews, 159, 35-46.

Lioubimtseva, E., \& Henebry, G. M. (2009). Climate and environmental change in arid Central Asia: Impacts, vulnerability, and adaptations. Journal of Arid Environments, 73(11), 963-977.

Litvinsky, B.A., Zhang, G., \& Samghabadi, R.S. (Eds.). (1996). History of civilizations of Central Asia Volume III, The crossroads of civilizations: A.D. 250 to 750. Multiple History Series, Paris: UNESCO Publishing.

Ma, J. Z., \& Edmunds, W. M. (2006). Groundwater and lake evolution in the Badain Jaran desert ecosystem, Inner Mongolia. Hydrogeology Journal, 14, 1231-1243.

Makhmadaliev, B., Kayumov, A., Novikov, V., Mustaeva, N., \& Rajabov, I. (2008). The second national communication of the republic of Tajikistan under the United Nations framework convention on climate change. Tajikistan: Dushanbe.

Malatesta, L., Castelltort, S., Mantellini, S., Picotti, V., Hajdas, I., Simpson, G., et al. (2012). Dating the irrigation system of the Samarkand Oasis: A geoarchaeological study. Radiocarbon, 54(1), 91-105. https://doi.org/10.2458/azu_js_rc.v54i1.15839.

Manz, B. (1989). The rise and rule of Tamerlane. Cambridge: Cambridge University Press.

Marshak, B. I. (2003). The archaeology of Sogdiana. The Silk Road, 1(2), 2-8.

Matthews, J. A., \& Briffa, K. R. (2005). The 'Little Ice Age': Reevaluation of an evolving concept. Geografiska Annaler, 87 A(1), 17-36. 
Mitchell, T. D., \& Jones, P. D. (2005). An improved method of constructing a database of monthly climate observations and associated high-resolution grids. International Journal of Climatology, 25, 693-712.

Mukminova, R. G., \& Mukhtarov, A. (2003). The Khanate (Emirate) of Bukhara. In A. Chahryar, I. Habib, \& K. M. Baipakov (Eds.), History of civilizations of Central Asia volume V, development in contrast: From the sixteenth to the mid-nineteenth century. Multiple History Series, Paris: UNESCO Publishing.

Narama, C. (2002). Late Holocene variation of the Raigorodskogo Glacier and climate change in the Pamir-Alai, central Asia. Catena, 48, 21-37.

Narama, C., Kicengge Kubota, J., Shatravin, V., Duishonakunov, M., Moholdt, G., \& Abdrakhmatov, K. (2010). The lake level changes in Central Asia during the last 1000 years based on historical map. In M. Watanabe \& J. Kubota (Eds.), Reconceptualising cultural and environmental change in Central Asia: an historical perspective on the future, Ili Project, Research Institute for Humanity and Nature, Kyoto, 11-27.

Opała, M., Niedźwiedź, T., Rahmonov, O., Owczarek, P., \& Małarzewski, Ł. (2017). Towards improving the Central Asian dendrochronological network-new data from Tajikistan, PamirAlay. Dendrochronologia, 41, 10-23. https://doi.org/10.1016/j.dendro.2016.03.006.

Opała-Owczarek, M., \& Niedźwiedź, T. (2018). Last 1100 years of precipitation variability in western Central Asia as revealed by tree-ring data from the Pamir-Alay. Quaternary Research, 1-15. https://doi.org/10.1017/qua.2018.21.

Opała-Owczarek, M., Owczarek, P., Rahmonov, O., \& Niedźwiedź, T. (2018). The first dendrochronological dating of timber from Tajikistan — potential for developing a millennial tree-ring record. Tree-Ring Research, 74(2), 50-62. https://doi.org/10.3959/1536-1098-74.1.50.

Owczarek, P., Opała-Owczarek, M., Rahmonov, O., \& Mendecki, M. (2017). 100 years of earthquakes in the Pamir region as recorded in juniper wood: A case study of Tajikistan. Journal of Asian Earth Sciences, 138, 173-185. https://doi.org/10.1016/j.jseaes.2017.02.011.

Owczarek, P., Opała-Owczarek, M., Rahmonov, O., Razzokov, A., Jary, Z., \& Niedźwiedź, T. (2018). Relationships between loess and the Silk Road reflected by environmental change and its implications for human societies in the area of ancient Panjikent, central Asia. Quaternary Research, 89(3), 691-701. https://doi.org/10.1017/qua.2017.69

Panthi, S., Bräuning, A., Zhou, Z. K., \& Fan, Z. X. (2017). Tree rings reveal recent intensified spring drought in the central Himalaya. Nepal Global and Planetary Change, 157, 26-34.

Paul, J. (1993). The histories of Samarqand. Studia Iranica, 22, 69-92.

Pederson, N., Hessl, A. E., Baatarbileg, N., Anchukaitis, K. J., \& Di Cosmo, N. (2014). Pluvials, droughts, the Mongol Empire, and modern Mongolia. Proceedings of the National Academy of Sciences, 111(12), 4375-4379. https://doi.org/10.1073/pnas.1318677111.

Putnam, A. E., Putnam, D. E., Andreu-Hayles, L., Cook, E. R., Palmer, J. G., Clark, E. H., et al. (2016). Little Ice Age wetting of interior Asian deserts and the rise of the Mongol Empire. Quaternary Science Reviews, 131, 33-50.

Rahmonov, O., Rahmonov, M., Opała-Owczarek, M., Owczarek, P., Niedźwiedź, T., \& MygaPiątek, U. (2017a). Ecological and cultural importance of juniper ecosystem in the area of Zeravshan valley (Tajikistan) on the background of environmental condition and anthropogenic hazards. Geographia Polonica, 90, 441-461. https://doi.org/10.7163/GPol.0110.

Rahmonov, O., Szczypek, T., Niedźwiedź, T., Myga-Piątek, U., Rahmonov, M., \& Snytko, V. A. (2017b). The human impact on the transformation of juniper forest landscape in the western part of the Pamir-Alay range (Tajikistan). Environmental Earth Sciences, 76, 324. https://doi.org/10. 1007/s12665-017-6643-4.

Schafer, E. H. (1963). The golden peaches of samarkand: A study of T'ang exotics. Berkeley and Los Angeles, USA: University of California Press.

Schurr, B., Ratschbacher, L., Sippl, C., Gloaguen, R., Yuan, X., \& Mechie, J. (2014). Seismotectonics of the Pamir. Tectonics, 33, 1501-1518. https://doi.org/10.1002/2014TC003576. 
Seim, A., Omurova, G., Azisov, E., Musuraliev, K., Aliev, K., Tulyaganov, T., et al. (2016). Climate change increases drought stress of Juniper trees in the mountains of Central Asia. PLoS One, 11(4), e0153888. https://doi.org/10.1371/journal.pone.0153888.

Shah, S. K., Pandey, U., \& Mehrotra, N. (2018). Precipitation reconstruction for the Lidder Valley, Kashmir Himalaya using tree-rings of Cedrus deodara. International Journal of Climatology, 38, 758-773. https://doi.org/10.1002/joc.5405.

Sidle, R. C., Taylor, D., Lu, X. X., Adger, W. N., Lowe, D. J., de Lange, W. P., et al. (2004). Interactions of natural hazards and society in Austral-Asia: Evidence in past and recent records. Quaternary International, 118(119), 181-203.

Solomina, O. N., Bradley, R. S., Jomelli, V., Geirsdottir, A., Kaufman, D. S., Koch, J., et al. (2016). Glacier fluctuations during the past 2000 years. Quaternary Science Reviews, 149, 61-90.

Sorrel, P., Popescu, S.-M., Head, M. J., Suc, J. P., Klotz, S., \& Oberhänsli, H. (2006). Hydrographic development of the Aral Sea during the last 2000 years based on a quantitative analysis of dinoflagellate cysts. Palaeogeography, Palaeoclimatology, Palaeoecology, 234, 304-327. https:// doi.org/10.1016/j.palaeo.2005.10.012.

Sorrel, P., Popescu, S., Klotz, S., Suc, J., \& Oberhänsli, H. (2007). Climate variability in the Aral Sea basin (Central Asia) during the late Holocene based on vegetation changes. Quaternary Research, 67(3), 357-370. https://doi.org/10.1016/j.yqres.2006.11.006.

Speer, J. H. (2010). The fundamentals of tree-ring research. Tucson, AZ: University of Arizona Press.

Thompson, L. G., Mosley-Thompson, E., Davis, M. E., Lin, P. E., Henderson, K. A., Cole-Dai, J., et al. (1995). A 1000 year climate ice-core record from the Guliya ice cap, China: Its relationship to global climate variability. Annals of Glaciology, 21, 175-181.

Treydte, K. S., Schleser, G. H., Helle, G., Frank, D. C., Winiger, M., Haug, G. H., et al. (2006). The twentieth century was the wettest period in northern Pakistan over the past millennium. Nature, 440, 1179-1182. https://doi.org/10.1038/nature04743.

Wei, Z., Rosen, A. M., Fang, M., Su, Y., \& Zhang, X. (2015). Macro-economic cycles related to climate change in dynastic China. Quaternary Research, 83, 13-23.

Weiss, H., \& Bradley, R. S. (2001). What drives societal collapse? Science, 291, 609-610.

Wigley, T. M. L., Briffa, K. R., \& Jones, P. D. (1984). On the average value of correlated time series with applications in dendroclimatology and hydrometeorology. Journal of Climate and Applied Meteorology, 23(2), 201-213.

Williams, M. W., \& Konovalov, V. G. (2008). Central Asia temperature and precipitation data, 1879-2003. Boulder, Colorado: USA. NSIDC: National Snow and Ice Data Center. http://dx.doi. org/10.7265/N5NK3BZ8.

WinDENDRO. (2006). Manual. Regent Instrument INC, Quebec, Canada.

Wolff, C., Plessen, B., Dudashvilli, A. S., Breitenbach, S. F. M., Cheng, H., Edwards, L. R., et al. (2017). Precipitation evolution of Central Asia during the last 5000 years. The Holocene, 27(1), 142-154. https://doi.org/10.1177/0959683616652711.

Yadav, R. R., Gupta, A. K., Kotlia, B. S., Singh, V., Misra, K. G., Yadava, A. K., \& Singh, A. K. (2017). Recent wetting and glacier expansion in the Northwest Himalaya and Karakoram. Scientific Reports, 7. https://doi.org/10.1038/s41598-017-06388-5.

Yadava, A. K., Bräuning, A., Singh, J., \& Yadav, R. R. (2016). Boreal spring precipitation variability in cold arid western Himalaya during the last millennium and its relationship with hydrological records and human history. Quaternary Science Reviews, 144, 28-43.

Yang, B., Wang, J., Bräuning, A., Dong, Z., \& Esper, J. (2009). Late Holocene climatic and environmental changes in arid central Asia. Quaternary International, 194, 68-78.

Yao, T. D., Thompson, L. G., Qin, D. H., Tian, L. D., Jiao, K. Q., Yang, Z. H., et al. (1996). Variations in temperature and precipitation in the past 2000a on the Xizang (Tibet) Plateau-Guliya ice core record. Science in China, Series D, 39, 425-433.

Yin, J., Su, Y., \& Fang, X. (2016). Climate change and social vicissitudes in China over the past two millennia. Quaternary Research, 86, 133-143. 
Zech, W., Glaser, B., Ni, A., Petrov, M., \& Lemzin, I. (2000). Soil as indicators of the Pleistocene and Holocene landscape history: Alay range (Kyrgyzstan). Quaternary International, 65(66), $161-170$.

Zhang, T., Zhang, R., Yuan, Y., Gao, Y., Wei, W., Diushen, M., et al. (2015). Reconstructed precipitation on a centennial timescale from tree rings in the western Tien Shan Mountains, Central Asia. Quaternary International, 358, 58-67.

Open Access This chapter is licensed under the terms of the Creative Commons Attribution 4.0 International License (http://creativecommons.org/licenses/by/4.0/), which permits use, sharing, adaptation, distribution and reproduction in any medium or format, as long as you give appropriate credit to the original author(s) and the source, provide a link to the Creative Commons license and indicate if changes were made.

The images or other third party material in this chapter are included in the chapter's Creative Commons license, unless indicated otherwise in a credit line to the material. If material is not included in the chapter's Creative Commons license and your intended use is not permitted by statutory regulation or exceeds the permitted use, you will need to obtain permission directly from the copyright holder. 